Proc. Estonian Acad. Sci. Geol., 2006, 55, 2, 128-155

\title{
Frequency patterns of chitinozoans, scolecodonts, and conodonts in the upper Llandovery and lower Wenlock of the Paatsalu core, western Estonia
}

\author{
Olle Hints $^{\mathrm{a}}$, Mairy Killing ${ }^{\mathrm{a}, \mathrm{b}}$, Peep Männik ${ }^{\mathrm{a}}$, and Viiu Nestor ${ }^{\mathrm{a}}$ \\ ${ }^{a}$ Institute of Geology at Tallinn University of Technology, Estonia pst. 7, 10143 Tallinn, Estonia; \\ olle@gi.ee,mairy@gi.ee,mannik@gi.ee,vnestor@gi.ee \\ ${ }^{\mathrm{b}}$ Department of Mining, Tallinn University of Technology, Ehitajate tee 5, 19086 Tallinn, Estonia
}

Received 5 December 2005, in revised form 27 February 2006

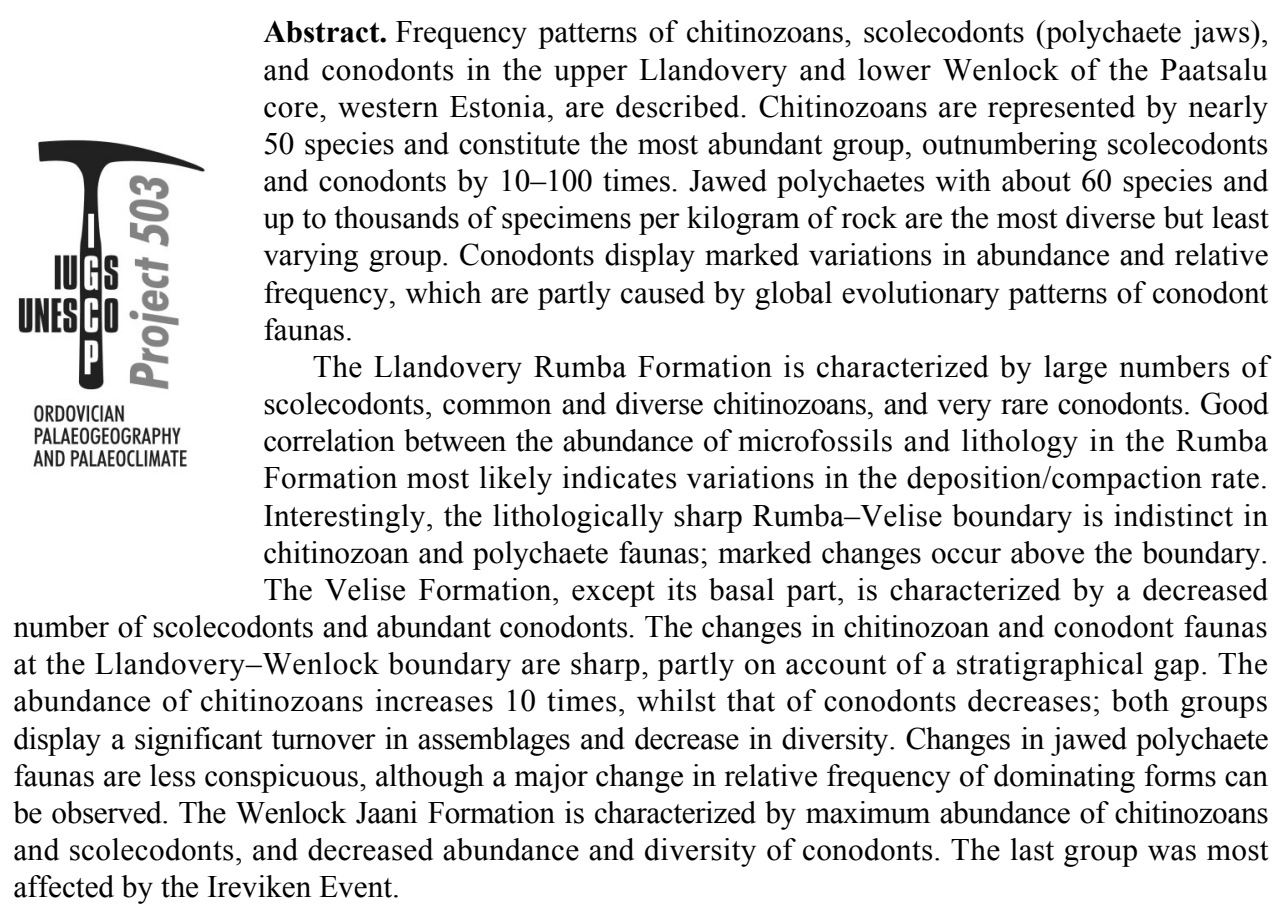

Key words: microfossil dynamics, frequency patterns, diversity, chitinozoans, scolecodonts, conodonts, Silurian, Estonia. 


\section{INTRODUCTION}

Quantitative data are essential for analysing palaeoecology and dynamics of fossil faunas. Moreover, numerical data on fossil distributions may contribute to a better understanding of palaeoenvironments and depositional regime, and improve stratigraphical resolution. The numerical specimen-level data on Early Palaeozoic fossil distribution are nevertheless limited. The dynamics of different fossil groups has been analysed jointly and in a detailed temporal and spatial framework only in a few studies. The first and perhaps still the most thorough study is that of Jaanusson et al. (1979) on the lower Wenlock strata of the Vattenfallet section, Gotland, Sweden.

The present study focuses broadly on the same interval, the upper Llandovery to lower Wenlock, of the Paatsalu drill core, western mainland Estonia. This interval was selected for quantitative study for a number of reasons. Firstly, much detailed biostratigraphical, but also chemostratigraphical and sedimentological background information is available from other coeval Estonian sections and elsewhere in the world. Secondly, this interval spans across an internationally recognized series boundary and embraces the best known Silurian event - the Ireviken Event, which is associated with oceanic changes, a stable isotope excursion, and extinction in several fossil groups (for a review see Jeppsson 2005 and references therein). Thirdly, the transition from the Rumba to Velise formations embraces a supposedly rapid facies change that reflects the most extensive flooding of the Baltic Shelf during the Silurian (Nestor \& Einasto 1997). The primary aim of our study was to document and analyse the frequency patterns of chitinozoans, scolecodonts, and conodonts. These groups are very common and diverse in Silurian rocks and represent different modes of life and ecological niches. It was of particular interest to explore if the curves of absolute and relative frequency of the three groups (and individual taxa) correlate with each other and with the palaeoenvironmental settings, and if the frequency data might be useful for stratigraphy and biofacies analysis.

The previous knowledge of frequency patterns of chitinozoans, scolecodonts, and conodonts in the Baltic Silurian is uneven. Conodonts are best known in this respect, but the published record on quantitative data is still limited (e.g. Jeppsson 1979). Some data on scolecodonts are available from Gotland (Bergman 1979, 1989; Eriksson 1997, 2006a; Eriksson et al. 2004). Little is known about the dynamics of chitinozoans (Laufeld 1979), however, several studies provide semiquantitative data (Nestor 1994) or analyse the abundance and diversity on a larger scale (Kaljo et al. 1986). Other acid-resistant microfossils encountered during this study include acritarchs, foraminiferans, melanoscleritoids, chitinous hydroids, and graptolite siculae, but these were not studied quantitatively.

The following measures are used to characterize the quantitative data set: abundance ( $=$ absolute frequency, the number of specimens per gram or kilogram of rock), relative frequency (percentage of a taxon within the group), taxic 
diversity (the number of species or genera in a sample), and diversity index (calculated using the well-known Shannon formula

$$
H=-\sum\left(\left(n_{i} / n\right) \ln \left(n_{i} / n\right)\right)
$$

where $n$ is the total number of individuals and $n_{i}$ is the number of individuals of taxon $i$ ). Further methodological details are discussed below for each of the groups studied.

Scolecodonts and conodonts were extracted by acid digestion from ca 300$500 \mathrm{~g}$ samples, whilst 5-50 grams of each sample were treated separately for chitinozoans. The residues were sieved through $53 \mu \mathrm{m}$ (chitinozoans) or $63 \mu \mathrm{m}$ (scolecodonts and conodonts) screens. All microfossils were then picked from the residues, identified, and counted; the chitinozoans by M. Killing and V. Nestor, scolecodonts by O. Hints, and conodonts by P. Männik. Samples, residues, and all specimens are deposited at the Institute of Geology at Tallinn University of Technology (abbreviated as GIT); for figured specimens the collection number 493 is allocated.

\section{LOCALITY AND STRATIGRAPHY}

The Paatsalu (527) drilling site is located in western mainland Estonia, close to the coast of the Baltic Sea, ca $10 \mathrm{~km}$ south of the village of Virtsu (Fig. 1). The $208.5 \mathrm{~m}$ deep borehole penetrates Wenlock, Llandovery, and Upper Ordovician strata.

The upper Llandovery to lower Wenlock succession considered in the present paper is composed of nodular limestones, mainly wacke- to packstones, of the Rumba Formation and dolomitic marlstones of the Velise and Jaani formations (see Fig. 2). Chitinozoans were studied also from the upper part of the Nurmekund Formation. The lithology and biostratigraphy of these stratigraphical units have been discussed in detail in several earlier papers (Kaljo 1970; Einasto et al. 1972; Jeppsson \& Männik 1993; Nestor 1997; Nestor \& Einasto 1997; Nestor \& Nestor 2002; Kiipli 2004; Harris et al. 2005). A generalized lithological log of the Paatsalu section is given in Fig. 2.

In order to facilitate direct comparison of quantitative palaeontological data with rock characteristics, and thereby with the palaeoenvironment and sedimentary processes, all samples used for microfossil extraction were also studied by means of carbonate analysis and thin sections. The carbonate analysis shows that the rocks of the Nurmekund and Rumba formations contain less than $25 \%$ insoluble residue and are in part strongly dolomitized. The levels of dolomitization, for example the top of the Nurmekund Formation (samples OM4-5 and OM4-6), may be related to hiatuses. The basal part of the Velise Formation is very clayey, containing nearly $80 \%$ insoluble residue. In successive strata the clay content decreases on account of dolomite, whereas calcite is almost missing. 


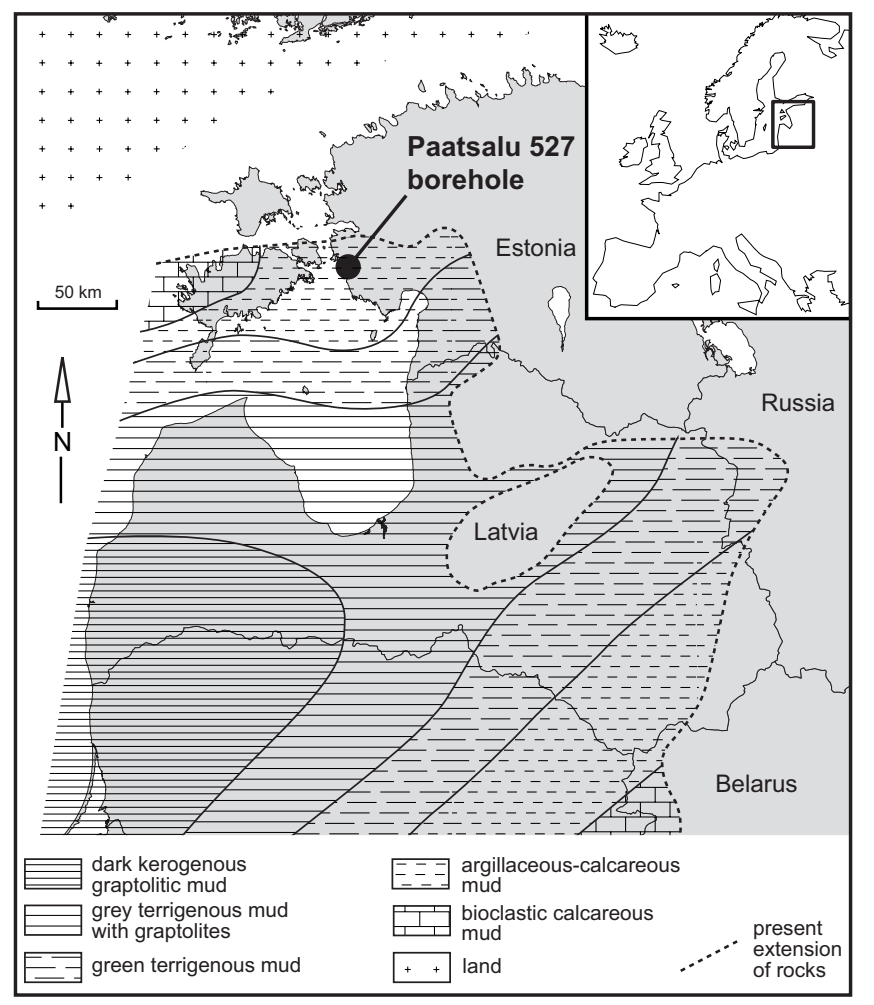

Fig. 1. Location of the Paatsalu (527) borehole and general palaeogeographical situation during mid-Jaani time (early Wenlock, topmost part of the interval studied). Facies are given after Nestor \& Einasto (1997).

The content of bioclastic material is highest in the Rumba Formation but rather low (less than 10\%) in under- and overlying units. The only exception is an interval in the Velise-Jaani transition, where bioclastic material accounts to nearly 30\% (OM4-38). The skeletal grains in the Rumba Formation are derived mainly from echinoderms (ca 50\%), brachiopods, and bryozoans. Due to dolomitization and recrystallization, the bioclastic material is poorly preserved in most of the Nurmekund, Velise, and Jaani formations; hence its taxonomic composition remains largely unknown. However, echinoderms and brachiopods dominate in the middle part of the Velise Formation (OM4-34 and OM4-35) and trilobites make up about $50 \%$ of the bioclasts in the upper part of the succession (OM4-45 and OM4-46; Fig. 2).

The upper Llandovery and lower Wenlock biostratigraphy of shallow shelf areas, including the Paatsalu locality, is based primarily on chitinozoans and conodonts. Integrated studies of basin successions have enabled also tying the conodont and chitinozoan zones with the standard graptolite zonation (Loydell et al. 1998, 2003). 


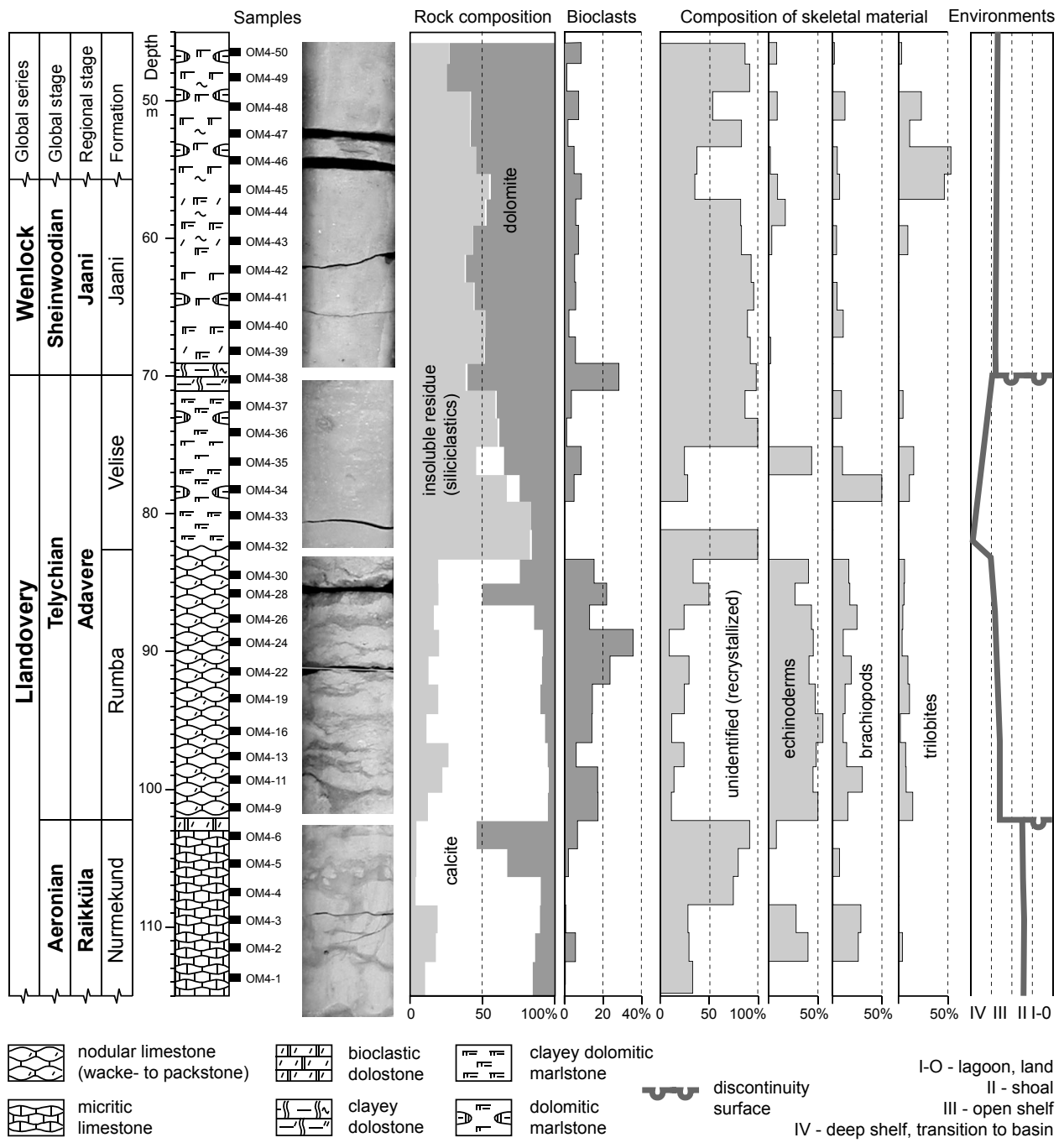

Fig. 2. Stratigraphy, generalized lithology, content of calcite, dolomite and insoluble residue, and content and composition of skeletal material in the upper Raikküla, Adavere, and Jaani stages in the Paatsalu core. For chitinozoan and conodont biozones see Figs 3 and 5. The lithological column redrawn after Einasto (unpublished data), sea-level curve after Nestor \& Einasto (1997).

The results of the current sampling of the upper Llandovery and lower Wenlock strata coupled with earlier data on conodonts and chitinozoans allow rather precise biostratigraphical dating of the succession. The lowermost part of the interval is characterized by the Euconochitina electa, Ancyrochitina convexa, and Conochitina alargada chitinozoan zones. The lower part of the Conochitina malleus Zone (Nestor et al. 2003) is missing, indicating a gap between the Nurmekund and 
Rumba formations (but also between the Raikküla and Adavere stages and probably between the Aeronian and Telychian). The stratigraphical and spatial extent of this gap has been recognized and discussed earlier by, e.g., Nestor (1976) and Nestor (1997).

The Eisenackitina dolioliformis Zone ranges through most of the Rumba Formation and lower part of the Velise Formation, and is followed by the Angochitina longicollis, Conochitina proboscifera, and Conochitina acuminata zones. At the lithologically distinct Velise-Jaani transition, the Margachitina margaritana Zone sensu stricto (i.e., where M. margaritana co-occurs with A. longicollis) is missing. According to Nestor (2005), the Llandovery-Wenlock boundary is located within the latter zone. Hence, it seems very likely that in the Paatsalu core the gap spans across the topmost Llandovery as well as the basal Wenlock (see also discussion in Nestor \& Nestor 2002). The boundary is succeeded by chitinozoan Interzone IV (Nestor 1994) and the Conochitina mamilla and Conochitina tuba zones.

Conodonts are too rare in the Nurmekund and Rumba formations to allow recognition of zones in this interval. The appearance of Pterospathodus eopennatus ssp. n. 1 in sample OM4-30 indicates that the base of the P. eopennatus ssp. n. 1 Zone lies in the upper part of the Rumba Formation. Conodonts become abundant in the basal Velise Formation, and successive zones, primarily based on the Pterospathodus lineage, can be followed throughout the formation. At the VeliseJaani transition, the Upper Pseudooneotodus bicornis, and the Lower and Upper Pterospathodus pennatus procerus zones are missing, confirming the conclusions based on the chitinozoan succession (see above). The Ireviken Event interval recognized in more complete successions in Estonia and Gotland (Jeppsson \& Männik 1993) is almost entirely missing in the Paatsalu section (only datum points 1 and 8 can be identified). Above this gap, the Lower and Upper Kockelella ranuliformis zones are recognized.

In a sequence stratigraphical framework, the Raikküla-Adavere transition corresponds to a large-scale sequence boundary (according to Harris et al. 2005 to the boundary between two "supersequences"), followed by a major flooding of the shelf during Adavere time. That sea-level rise caused laterally extensive spreading of lime muds (Rumba Formation) unconformably covering older deposits and was followed by further deepening of the basin and extensive formation of terrigenous muds (Velise Formation). These strata are overlain by a shallowing-upward package which ends up in widespread shoal deposits (starting slightly above the sampled interval in the Paatsalu section).

A succession of sediments formed in variable environmental settings ranging from shoal to deep shelf was recognized in the studied interval (Fig. 2; Nestor \& Einasto 1997). In terms of benthic assemblage zones (BA, sensu Boucot 1975), these environments correspond to the BA2-3 to BA4-5 zones. 


\section{MICROFOSSIL FREQUENCY PATTERNS}

\section{Chitinozoans}

The collection of chitinozoans consists of nearly 50 species. One sample usually contains $5-8$, but occasionally 12 different species, which is slightly more than reported from the lower Wenlock of Gotland (Laufeld 1979). The latter fact may, however, result partly from the recent progress in chitinozoan studies and systematics. The abundance of chitinozoans (Fig. 3) varies considerably and ranges from less than one to about 20 specimens per gram of rock in the Llandovery Nurmekund, Rumba, and Velise formations (i.e., in the Llandovery). The abundance increases markedly at the Llandovery-Wenlock boundary and ranges from 30 to 170 vesicles per gram in the Wenlock. The maximum was recorded in sample OM4-45. It remains to be tested if the chitinozoan abundance displays the same trend in stratigraphically more complete sections.

The abundance of chitinozoans in the Jaani Formation slightly exceeds the values reported by Laufeld (1979) for the lower Wenlock Upper Visby Formation of the Vattenfallet section, Gotland, where the corresponding values range from ca 10 to 100 . However, the abundance varies rather widely in both sections.

The most common genera that occur throughout the studied interval are Conochitina and Ancyrochitina (see Plate I for most common species). The former generally dominates in the Raikküla Stage and the latter in the Adavere and Jaani stages. At some levels also Eisenackitina, Margachitina, Angochitina, and Bursachitina form a significant part of the assemblage (Fig. 3).

Commonly, the dominant species constitutes $50-70 \%$ of the assemblage, but exceptionally one species can make up more than $95 \%$ of all specimens (Euconochitina electa in sample OM4-1; see Fig. 3). Other species that may strongly dominate the assemblage are Conochitina elongata and C. iklaensis in the Nurmekund and basal Rumba formations and Ancyrochitina ancyrea and A. primitiva in the remaining part of the sequence (except for the few levels rich in Angochitina longicollis, Bursachitina spp. or M. margaritana).

Despite different sampling density and extent of the study interval, this pattern is very similar to the early Wenlock chitinozoan dynamics. Alternating Conochitina and Ancyrochitina are complemented by Angochitina, Margachitina, and few others at certain levels (Laufeld 1979).

Fig. 3. Distribution of selected chitinozoan species and genera. Relative frequency is only shown for taxa that account for more than ca $10 \%$ of the assemblage. To the left of the absolute frequency curve the corresponding numerical value and actual number of specimens counted in each sample (in parentheses) are indicated. Chitinozoan biozones after Nestor $(1994,2005)$ and Nestor \& Nestor (2002). Diversity of chitinozoans is illustrated in Fig. 6. For lithological key see Fig. 2. 


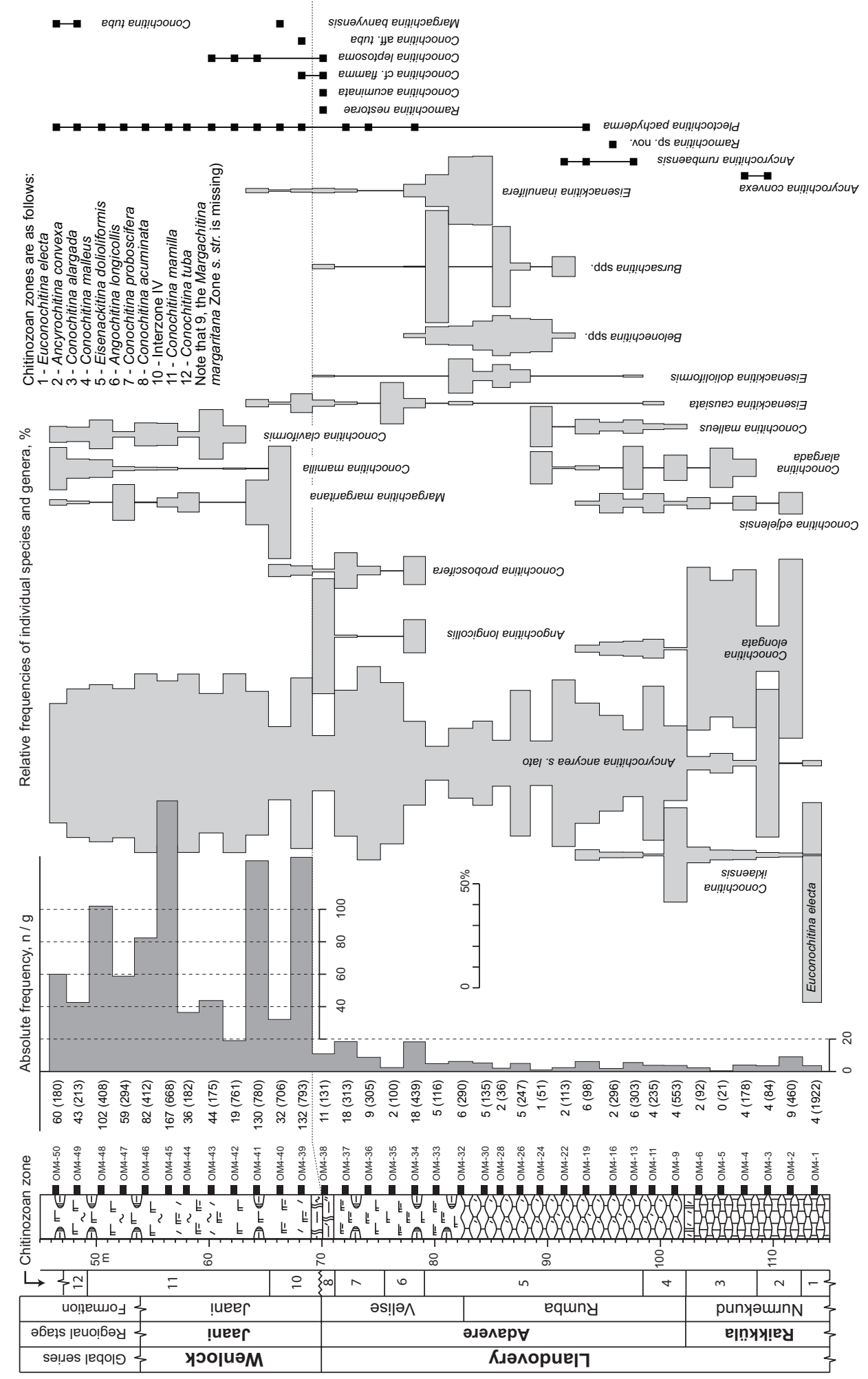


PLATE I

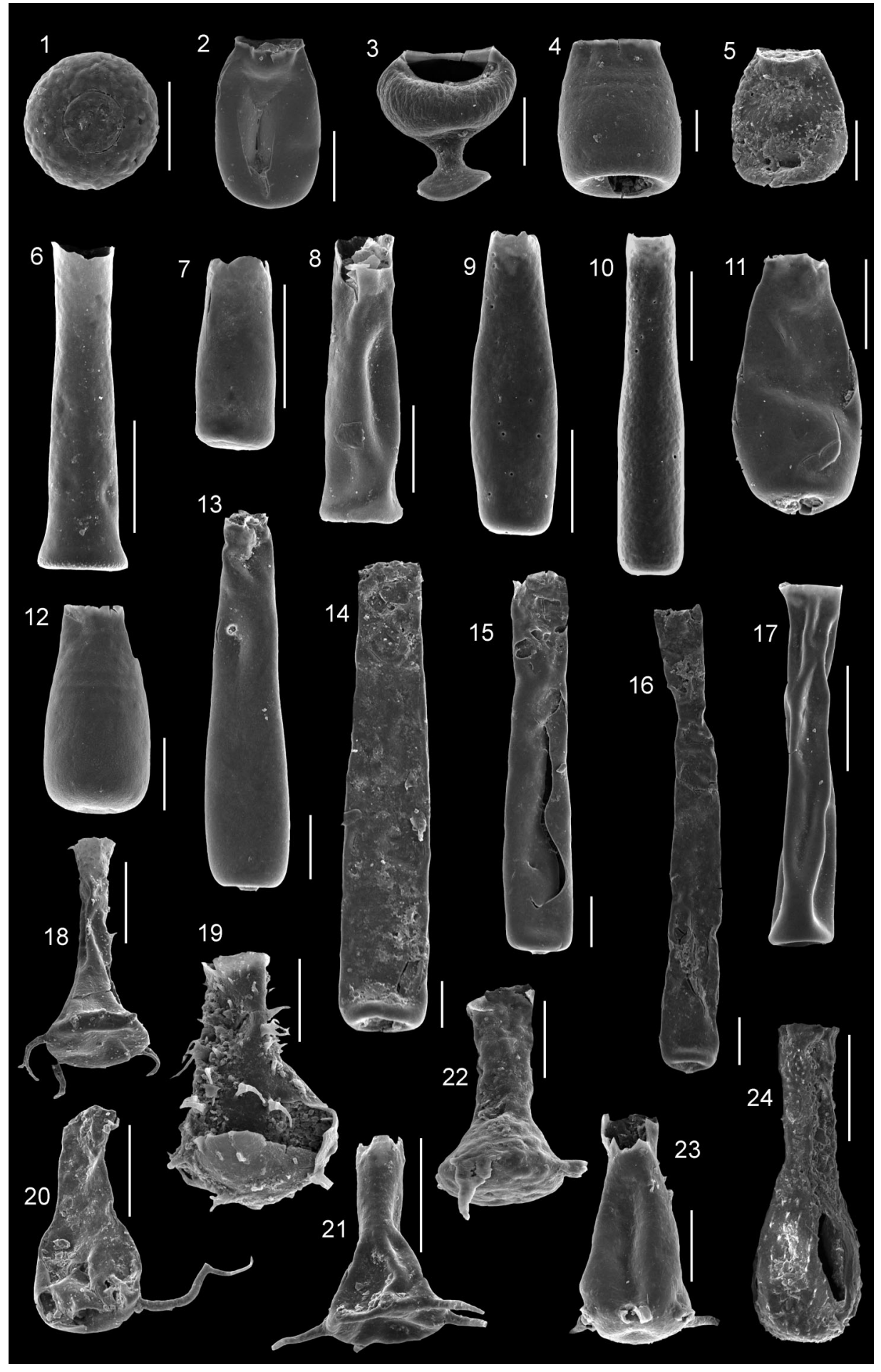


The taxic diversity is relatively consistent with abundance in the Llandovery. In the Wenlock, however, the high abundance samples are not necessarily related to the highest number of species (Fig. 3). The Shannon diversity index for chitinozoan assemblages displays a notable drop in the Velise Formation, and in the overlying strata remains below the average recorded in the Rumba and lower Velise formations. Due to rather small average sample weight, very rare species may be under-represented, resulting in lower diversity.

Laufeld (1974) concluded that the abundance of chitinozoans on Gotland is almost directly proportional to the content of clay and silt in the rocks: the more argillaceous the rocks, the more chitinozoans they contain. In the light of this, it is somewhat surprising that the most argillaceous interval, the Velise Formation, and its basal portion in particular, is only a little richer than the Rumba Formation (see also Nestor 1994).

\section{Explanation of Plate I}

Figs 1-24. Typical chitinozoans from the Llandovery-Wenlock boundary interval of the Paatsalu core. Scale bars correspond to $50 \mu \mathrm{m}$ (figs 1-5, 18-24) and $100 \mu \mathrm{m}$ (figs 6-17). 1. Calpichitina densa (Eisenack), GIT 493-1, sample OM4-42, depth 62.22 m, Jaani Formation, Wenlock. 2. Bursachitina nestorae Mullins \& Loydell, GIT 493-2, sample OM4-33, depth $80.10 \mathrm{~m}$, Velise Formation, Llandovery. 3. Margachitina margaritana (Eisenack), GIT 493-3, sample OM4-40, depth 66.25 m, Jaani Formation, Wenlock. 4. Eisenackitina inanulifera Nestor, GIT 493-4, sample OM4-33, depth 80.10 m, Velise Formation, Llandovery. 5. Eisenackitina causiata Verniers, GIT 493-5, sample OM4-34, depth 78.20 m, Velise Formation, Llandovery. 6. Euconochitina electa Nestor, GIT 493-6, sample OM4-1, depth 113.67 m, Nurmekund Formation, Llandovery. 7. Conochitina edjelensis Taugourdeau, GIT 493-7, sample OM4-2, depth $111.50 \mathrm{~m}$, Nurmekund Formation, Llandovery. 8. Conochitina cf. elongata Taugourdeau, GIT 493-8, sample OM4-2, depth $111.50 \mathrm{~m}$, Nurmekund Formation, Llandovery. 9. Conochitina iklaensis Nestor, GIT 493-9, sample OM4-9, depth 101.30 m, Rumba Formation, Llandovery. 10. Conochitina alargada Cramer, GIT 493-10, sample OM4-9, depth $101.30 \mathrm{~m}$, Rumba Formation, Llandovery. 11. Conochitina malleus (nomen nudum, Van Grootel), GIT 493-11, sample OM4-16, depth 95.76 m, Rumba Formation, Llandovery. 12. Conochitina cf. emmastensis Nestor, GIT 493-12, sample OM4-34, depth $78.20 \mathrm{~m}$, Velise Formation, Llandovery. 13. Conochitina proboscifera Eisenack, GIT 493-13, sample OM4-37, depth 72.10 m, Velise Formation, Llandovery. 14. Conochitina claviformis Eisenack, GIT 493-14, sample OM4-42, depth 62.22 m, Jaani Formation, Wenlock. 15. Conochitina mamilla Laufeld, GIT 493-15, sample OM4-40, depth 66.25 m, Jaani Formation, Wenlock. 16. Conochitina leptosoma Laufeld, GIT 493-16, sample OM4-42, depth 62.22 m, Jaani Formation, Wenlock. 17. Rhabdochitina sp., GIT 493-17, sample OM4-13, depth 97.60 m, Rumba Formation, Llandovery. 18. Ancyrochitina ancyrea Eisenack, GIT 493-18, sample OM4-28, depth $85.78 \mathrm{~m}$, Rumba Formation, Llandovery. 19. Ramochitina sp. (nov.), GIT 493-19, sample OM4-16, depth $95.76 \mathrm{~m}$, Rumba Formation, Llandovery. 20. Ancyrochitina porrectaspina Nestor, GIT 493-20, sample OM4-37, depth 72.10 m, Velise Formation, Llandovery. 21. Ancyrochitina primitiva Eisenack, GIT 493-21, sample OM4-22, depth 91.45 m, Nurmekund Formation, Llandovery. 22. Plectochitina pachyderma Laufeld, GIT 493-22, sample OM4-41, depth 64.23 m, Jaani Formation, Wenlock. 23. Ancyrochitina rumbaensis Nestor, GIT 493-23, sample OM4-19, depth 93.40 m, Rumba Formation, Llandovery. 24. Angochitina longicollis Eisenack, GIT 493-24, sample OM4-34, depth 78.20 m, Velise Formation, Llandovery. 


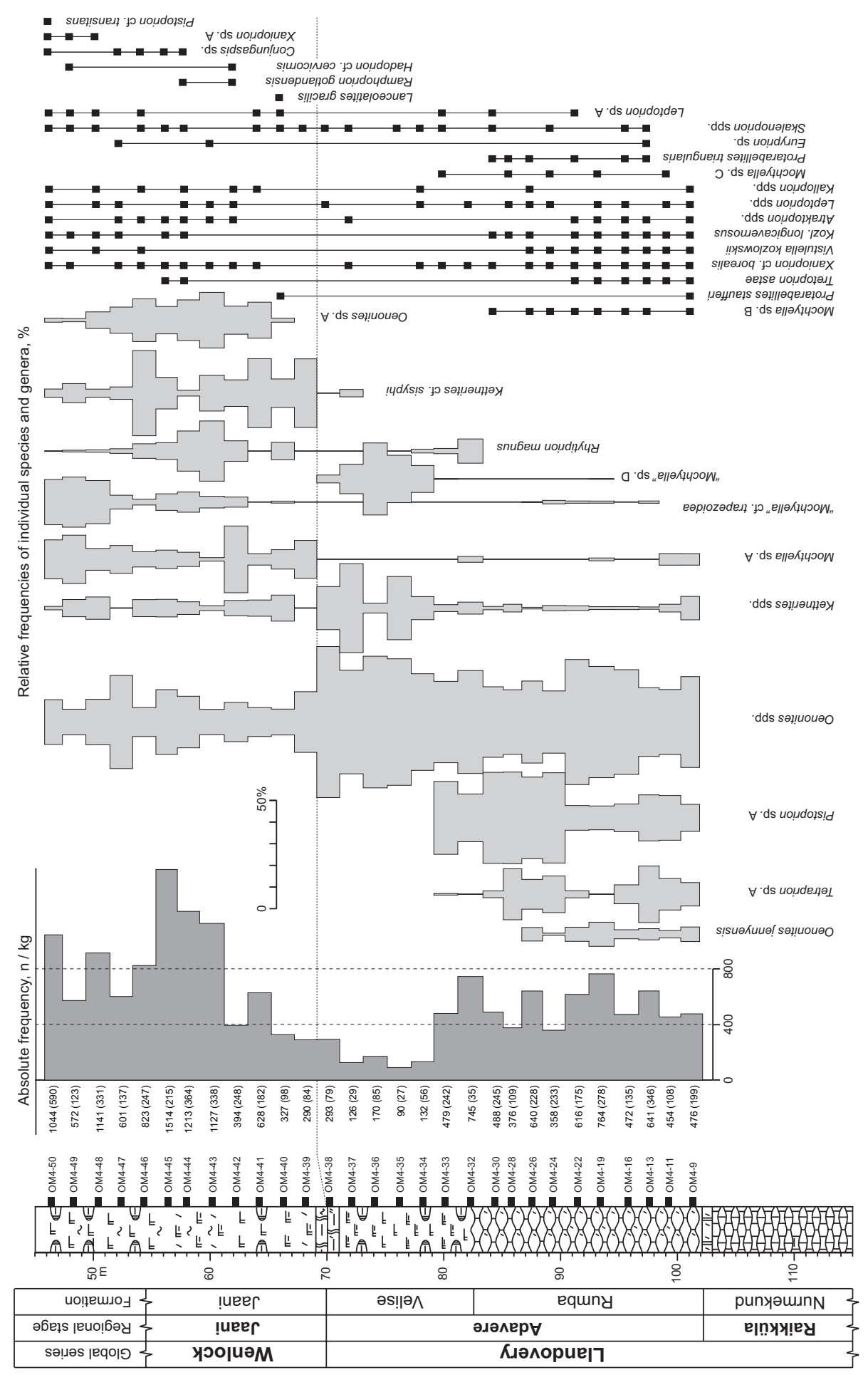




\section{Scolecodonts}

Scolecodonts were found in all samples, mostly in abundance. They make up the second most common acid-resistant microfossil group in most samples, next to chitinozoans (and likely acritarchs that have been overlooked in this study). Although the large numbers may partly result from shedding (see discussion in Eriksson 2006b), jaw-bearing polychaetes undoubtedly constituted a common faunal component of the benthic assemblages that inhabited the study area during the late Llandovery and early Wenlock.

The entire jawed polychaete fauna comprises approximately 60 apparatusbased species (see Plate II for selected forms). Up to 27 species were recorded in one sample. Nearly half of the species recovered are not yet formally described but are treated currently under open nomenclature, since systematics was beyond the scope of this study. A rigorous taxonomic analysis will nevertheless follow, utilizing material also from other Estonian sections and elsewhere, particularly Gotland.

The counts of jawed polychaete "specimens" referred to below and used in all calculations were obtained by the most frequent diagnostic element of each species (or genus) in a sample (Hints 1998, 2000). Usually this means counting left or right posterior maxillae. Other authors (e.g. Bergman 1989; Eriksson 1997, 2001, 2006a) have counted left and right posterior maxillae, resulting in counts that are up to two times higher for a given sample. Taken that polychaete jaw apparatuses usually contain many elements, some of which are not species- or genus-diagnostic, the plain count of all scolecodonts can be several times higher. Altogether some 5500 specimens were counted. In addition to the common detached elements, this number includes also more than 80 well-preserved jaw apparatuses.

The abundance of scolecodonts varies greatly, ranging from about 100 to 1500 specimens per kilogram of rock (Fig. 4). The Rumba and the lowermost Velise formations are characterized by a rich assemblage with approximately 500 specimens per kilogram. The abundance drops abruptly in the lower part of the Velise Formation and displays low but slightly increasing values throughout the rest of the formation. In the Jaani Formation, abundance continues to increase and reaches maximum values between depths of 55 and $60 \mathrm{~m}$ (Fig. 4).

The jawed polychaete fauna is dominated by polychaetaspids, mochtyellids, and paulitinids as would be expected from a Silurian assemblage (Eriksson et al. 2004, fig. 6). Polychaetaspids, particularly the genus Oenonites, account for a maximum of $70 \%$, mochtyellids reach $60 \%$, and paulinitids about $45 \%$ of all

Fig. 4. Distribution of selected polychaete taxa. Relative frequency is only shown for taxa that account for more than ca $10 \%$ of the assemblage. Note that the scolecodont counts are based on the most abundant element of the taxon in the sample. To the left of the absolute frequency curve the corresponding numerical value and actual number of specimens counted in each sample (in parentheses) are indicated. Diversity of jawed polychaetes is illustrated in Fig. 6. For lithological key see Fig. 2. 


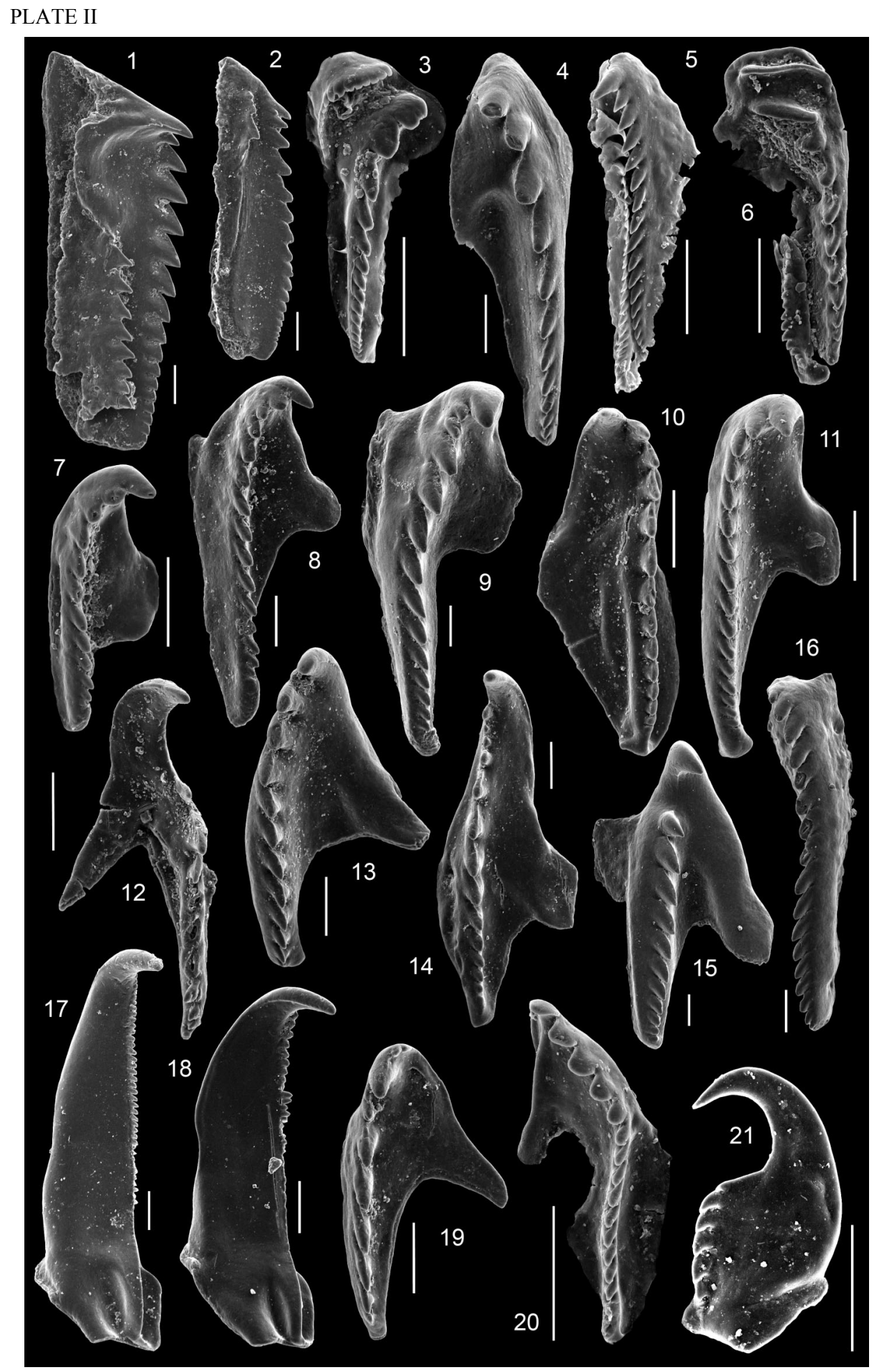


specimens. Oenonites is also the most species-rich genus, represented by more than 10 species. It is, however, usually not possible to identify them all and thus, except for O.jennyensis and Oenonites sp. A (Pl. II, fig. 7), they are grouped into Oenonites spp. in Fig. 4. Among the mochtyellids, Pistoprion and Mochtyella sensu lato are the most frequent forms. The latter group, representing at least three different genera that are yet to be formally described, contains ca 10 species, some of which are shown in Fig. 4 and Plate II. The paulinitids are represented by Kettnerites and Lanceolatites. The former genus varies greatly in frequency but occurs in all samples, whereas the latter is very rare.

Occasionally rhytiprionids, tetraprionids, and xanioprionids make up a considerable part of the assemblages. Other families like Ramphoprionidae, Atraktoprionidae, Kalloprionidae, Tretoprionidae, Conjungaspidae, and Hadoprionidae may be common in certain parts of the succession but far less abundant than the above mentioned taxa.

The stratigraphical ranges of individual species and genera are usually restricted to certain intervals of the succession studied (Fig. 4). For instance, O. jennyensis, Mochtyella sp. B, and Protarabellites triangularis have been

\section{Explanation of Plate II}

Figs 1-21. Selected scolecodonts. All in dorsal view, except 1 and 2 that are in left lateral view. Scale bars correspond to $100 \mu \mathrm{m}$. 1. "Mochtyella" cf. trapezoidea Kielan-Jaworowska, left MI, GIT 493-25, sample OM4-50, depth 46.60 m, Jaani Formation, Wenlock. 2. Mochtyella sp. A, right MI, GIT 493-26, sample OM4-48, depth 50.56 m, Jaani Formation, Wenlock. 3. "Mochtyella" sp. D, right MI, GIT 493-27, sample OM4-36, depth $74.23 \mathrm{~m}$, Velise Formation, Llandovery. 4. Pistoprion sp. A, left MI, GIT 493-28, sample OM4-13, depth $97.76 \mathrm{~m}$, Rumba Formation, Llandovery. 5. Tetraprion sp. A, left MI, GIT 493-29, sample OM4-13, depth 97.76 m, Rumba Formation, Llandovery. 6. Rhytiprion magnus Kielan-Jaworowska, left MI, GIT 493-30, sample OM4-43, depth $60.36 \mathrm{~m}$, Jaani Formation, Wenlock. 7. Oenonites sp. A, right MI, GIT 493-31, sample OM4-43, depth 60.36 m, Jaani Formation, Wenlock. 8. Oenonites sp., right MI, GIT 493-32, sample OM4-50, depth $46.60 \mathrm{~m}$, Jaani Formation, Wenlock. 9. Kozlowskiprion longicavernosus Kielan-Jaworowska, right MI, GIT 493-33, sample OM4-50, depth 46.60 m, Jaani Formation, Wenlock. 10. Oenonites jennyensis Eriksson, left MI, GIT 493-34, sample OM4-13, depth 97.76 m, Rumba Formation, Llandovery. 11. Oenonites jennyensis Eriksson, right MI, GIT 493-35, sample OM4-13, depth 97.76 m, Rumba Formation, Llandovery. 12. Hadoprion cf. cervicornis (Hinde), left MIII, GIT 493-36, sample OM4-48, depth 50.56 m, Jaani Formation, Wenlock. 13. Kalloprion sp., right MI, GIT 493-37, sample OM4-48, depth 50.56 m, Jaani Formation, Wenlock. 14. Ramphoprion gotlandensis Eriksson, right MI, GIT 493-38, sample OM4-48, depth $50.56 \mathrm{~m}$, Jaani Formation, Wenlock. 15. Leptoprion sp. A, right MI, GIT 493-39, sample OM4-48, depth $50.56 \mathrm{~m}$, Jaani Formation, Wenlock. 16. Xanioprion sp. A, right MI, GIT 493-40, sample OM4-50, depth $46.60 \mathrm{~m}$, Jaani Formation, Wenlock. 17. Lanceolatites gracilis Bergman, left MI, GIT 493-41, sample OM4-40, depth 66.38 m, Jaani Formation, Wenlock. 18. Kettnerites cf. sisyphi Bergman, left MI, GIT 493-42, sample OM4-43, depth $60.36 \mathrm{~m}$, Jaani Formation, Wenlock. 19. Kettnerites cf. sisyphi Bergman, right MII, GIT 493-43, sample OM4-50, depth 46.60 m, Jaani Formation, Wenlock. 20. Tretoprion astae Hints, left MI, GIT 493-44, sample OM4-13, depth 97.76 m, Rumba Formation, Llandovery. 21. Skalenoprion sp., right MI, GIT 493-45, sample OM4-40, depth $66.38 \mathrm{~m}$, Jaani Formation, Wenlock. 
recovered only from the Rumba Formation, Pistoprion sp. A, Tetraprion sp. A, and Mochtyella sp. C are restricted to the Rumba and lowermost Velise formations. Oenonites sp. A, Conjungaspis sp., Xanioprion sp. A, Hadoprion cervicormis, and Ramphoprion gotlandensis occur in the Jaani Formation, and Rhytiprion magnus is found in the Velise and Jaani formations.

However, for some of the mentioned species longer ranges have been reported from other localities. Eriksson (1997) described O. jennyensis from the lower Wenlock Högklint Formation of Gotland. Protarabellites triangularis ranges from the Slite Group (upper Sheinwoodian) to the Hamra Formation (Ludfordian) and $R$. gotlandensis throughout the Silurian of Gotland (Eriksson 2001, 2002; Eriksson et al. 2004). Pistoprion sp. A (=Eunicites serrula sensu Bergman 1979) has been reported previously from Gotland (Bergman 1979), Severnaya Zemlya (Männil \& Zaslavskaya 1985), and the Canadian Arctic (Hints et al. 2000). At least on Gotland, its distribution extends well into the Wenlock (Högklint Formation), where it is one of the most common species (Bergman 1979). Thus in many cases the stratigraphical ranges recorded in the Paatsalu section seem not to be true time constrained ranges, but represent local distribution intervals that result from environmental settings and facies changes.

The relative frequency patterns of individual taxa may also show distinct and regular changes. Among the dominant species, Pistoprion sp. A provides the best example. In the lower part of the Rumba Formation it makes up $10-20 \%$ of specimens, but between samples OM4-22 and OM4-24, its relative frequency increases abruptly several times, mainly on account of Oenonites spp. Although in terms of absolute frequency this growth is less prominent, displaying only twofold increase, it is unlikely to be a random change. Upsection, this species continues with a rather stable share until abrupt disappearance between samples OM4-33 and OM4-34. Notably its disappearance does not coincide with the sharp lithological change at the Rumba-Velise formation boundary. The genus reappears in the topmost sample, represented by $P$. cf. transitans. Studies on the Baltic Ordovician have shown that the distribution of Pistoprion is strongly faciescontrolled (Hints 2000, 2001) and events like volcanic ash-falls may affect this genus severely (Hints et al. 2003). Presumably, the same applied to Silurian representatives of Pistoprion. Mochtyella sp. A, "Mochtyella" sp. D, "Mochtyella" cf. trapezoidea, Oenonites sp. A, and R. magnus constitute other examples with rather well-formed peaks in frequency curves. The last species is known to be also facies-controlled, preferring distal muddy environments (Bergman et al. 2003).

The abundance and diversity of scolecodonts change very little at the Llandovery-Wenlock boundary. The assemblage structure, however, displays a notable turnover expressed in the disappearance of "Mochtyella" sp. D, decrease in polychaetaspids, and increase in the abundance of Kettnerites cf. sisyphi and Mochtyella sp. A. Rhytiprion magnus and Oenonites sp. A increase in abundance shortly above the boundary, where also L. gracilis shows up temporarily. 
Studying the polychaete fauna of the Ireviken Event interval of Gotland, Eriksson (2006a) concluded that the event had strong impact on polychaetes, especially at datum points 2 and 6.2 when several taxa disappeared and the assemblage structure changed drastically. Although the present sampling density is low and the most severely affected faunas may be missing in the Paatsalu section due to the stratigraphical gap, the frequency changes reported above may, at least partly, be related to the Ireviken Event.

The current study extends the ranges of several jawed polychaetes. For instance, some Silurian taxa, so far reported only from Wenlock or younger strata (see Bergman 1979; Eriksson 1997, 2001), apparently occur also in the Llandovery. The Late Ordovician taxa Tretoprion astae and Conjungaspis range into the Wenlock (see Hints 1999).

\section{Conodonts}

Conodonts occur in all samples. The count for each taxon was derived from the sum of all identifiable elements in the sample. Hence the results may be biased if different taxa had a significantly different number of elements in the apparatus. The abundance is not directly comparable with that of scolecodonts. The calculated number of specimens per kilogram of rock varies from 3 (sample OM4-28) to more than 4000 (sample OM4-38), the number of species per sample ranges from 1 to 18 (Figs 5,6). The relatively low number of taxa per sample evidently results in most cases from the inadequate size of the sample. For several reasons (e.g., assignment of several elements of Panderodus to a particular species is still problematic), in calculations of relative abundances of taxa, as a rule, data on genera rather than species were used. In calculations only the taxa represented by an adequate number of specimens to allow reliable statistics were taken into account. The distribution of these taxa is shown in Fig. 5 (common and stratigraphically important forms are illustrated on Pl. III), together with some stratigraphically important taxa, which were left out of the calculations because they are too rare.

Three distinct intervals, based on the number of taxa and specimens in the samples, can be recognized in the succession of conodonts. In the lower part of the studied section (from the uppermost Nurmekund to the upper Rumba formations), conodonts are rare, usually represented by less than 10 specimens (26 specimens as a maximum) per kilogram of rock. All these samples yielded Panderodus, some samples also a specimen or two of Ozarkodina excavata puskuensis. Pterospathodus eopennatus ssp. $\mathrm{n} .1$ appears in the uppermost Rumba Formation (sample OM4-30), indicating the corresponding biozone. As a rule, the Pterospathodus eopennatus ssp. $\mathrm{n}$. 1 Zone is characterized by a rich and variable conodont fauna (e.g. Männik 2003). The poor yield from this interval in the Paatsalu core is probably caused by ecological factors. 


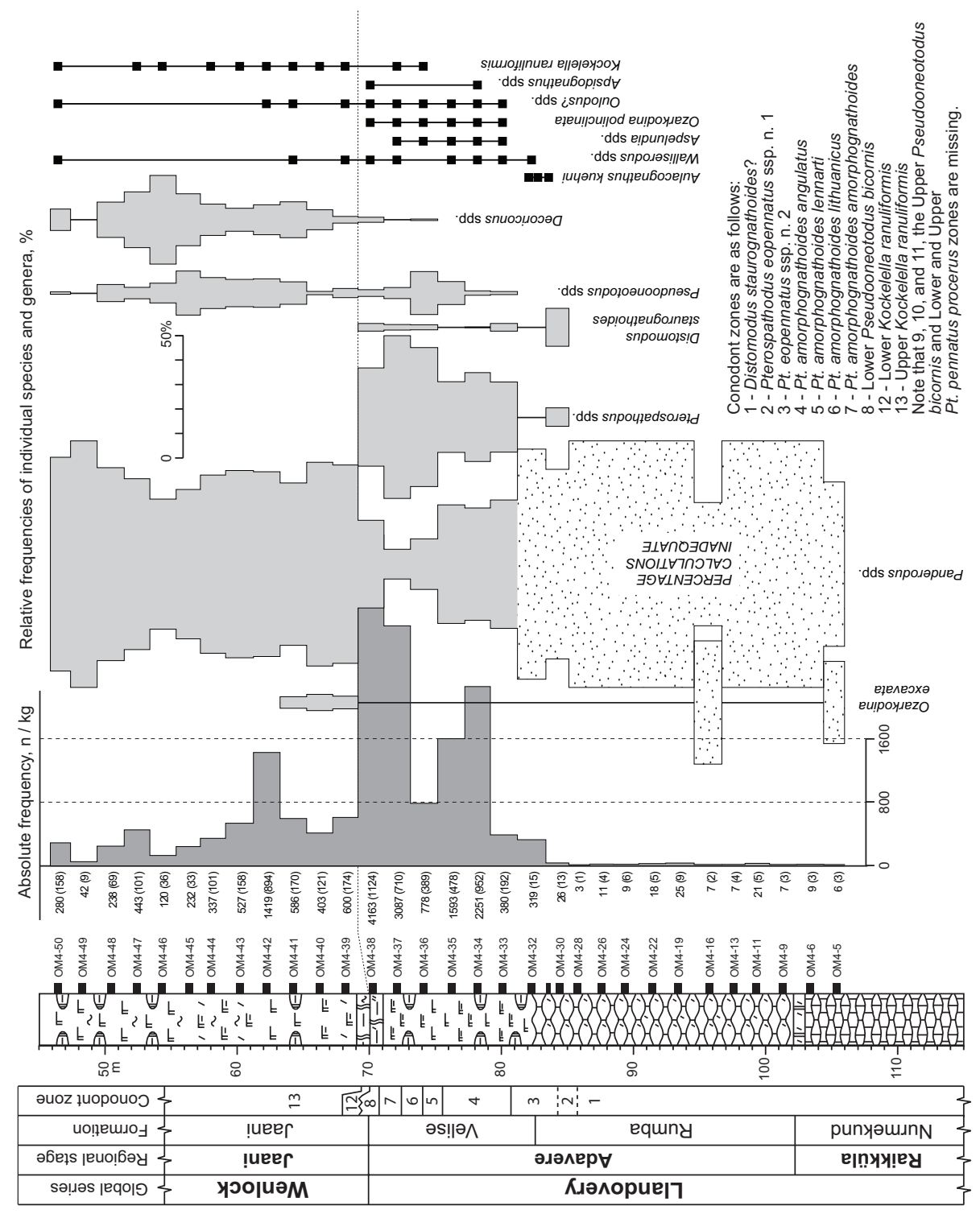


The Velise Formation contains the richest and most variable conodont fauna. The number of specimens per kilogram of rock increases continuously upwards, from 319 specimens in the lowermost sample (OM4-32) to 4163 in the topmost one (OM4-38). The lower number of specimens in sample OM4-36 might be related to the so-called lithuanicus event (Männik 2001). The number of conodont taxa per sample reaches its maximum (18) in the uppermost sample.

The fauna of the Velise Formation is dominated by Panderodus and Pterospathodus. Pseudooneotodus is quite common as well, particularly in sample OM4-36. Panderodus dominates in the lower part of the interval. Its relative abundance decreases upwards in the formation where Pterospathodus begins to dominate. Pterospathodus is represented by a succession of subspecies whose ranges do not overlap (biozones in Fig. 5). Panderodus is represented by several species, with $P$. greenlandensis and $P$. unicostatus being the most common in this section.

The number of specimens per kilogram drops from more than 4000 below the upper boundary of the Velise Formation to 600 above it. The number of taxa decreases rapidly and the composition of fauna changes considerably. Pterospathodus, Distomodus, most species of Panderodus and several other taxa disappear. These changes are caused by the well-known Ireviken Event (for an overview see Jeppsson 2005 and references therein). Due to a gap in the section (the Upper Pseudooneotodus bicornis, and Lower and Upper Pterospathodus pennatus procerus zones are missing, see also discussion above), only the lowermost and uppermost parts of the event are represented in the Paatsalu core and the step-by-step disappearance of taxa characteristic of the Ireviken Event (e.g. Jeppsson \& Männik 1993) cannot be observed. Above the event level, the fauna is strongly dominated by P. equicostatus. Quite common are also Decoriconus spp. and Pseudooneotodus spp. Other taxa, e.g., Kockelella ranuliformis, Walliserodus sp., and Oulodus? spp., occur sporadically and are represented by rare specimens. Ozarkodina excavata excavata, although relatively common, has been found in the lowermost samples of the interval only. The number of specimens per kilogram of rock, although somewhat variable, decreases gradually up to the top of the interval studied in the Paatsalu core. The number of taxa is also a little higher in the lower part of the interval. However, some variations in the number of taxa per sample in this part of the section (above ca $60 \mathrm{~m}$ depth) are most probably caused by differences in sample size - larger samples are needed to obtain reliable data on rare taxa.

Fig. 5. Distribution of conodonts. Relative frequency is only shown for taxa that account for more than ca $10 \%$ of the assemblage. Note that unlike scolecodonts, all elements of every species were counted, which results in higher numbers. Panderodus ssp. is not separated due to taxonomic complications. To the left of the absolute frequency curve the corresponding numerical value and actual number of specimens counted in each sample (in parentheses) is indicated. Diversity data are illustrated in Fig. 6. For lithological key see Fig. 2. 


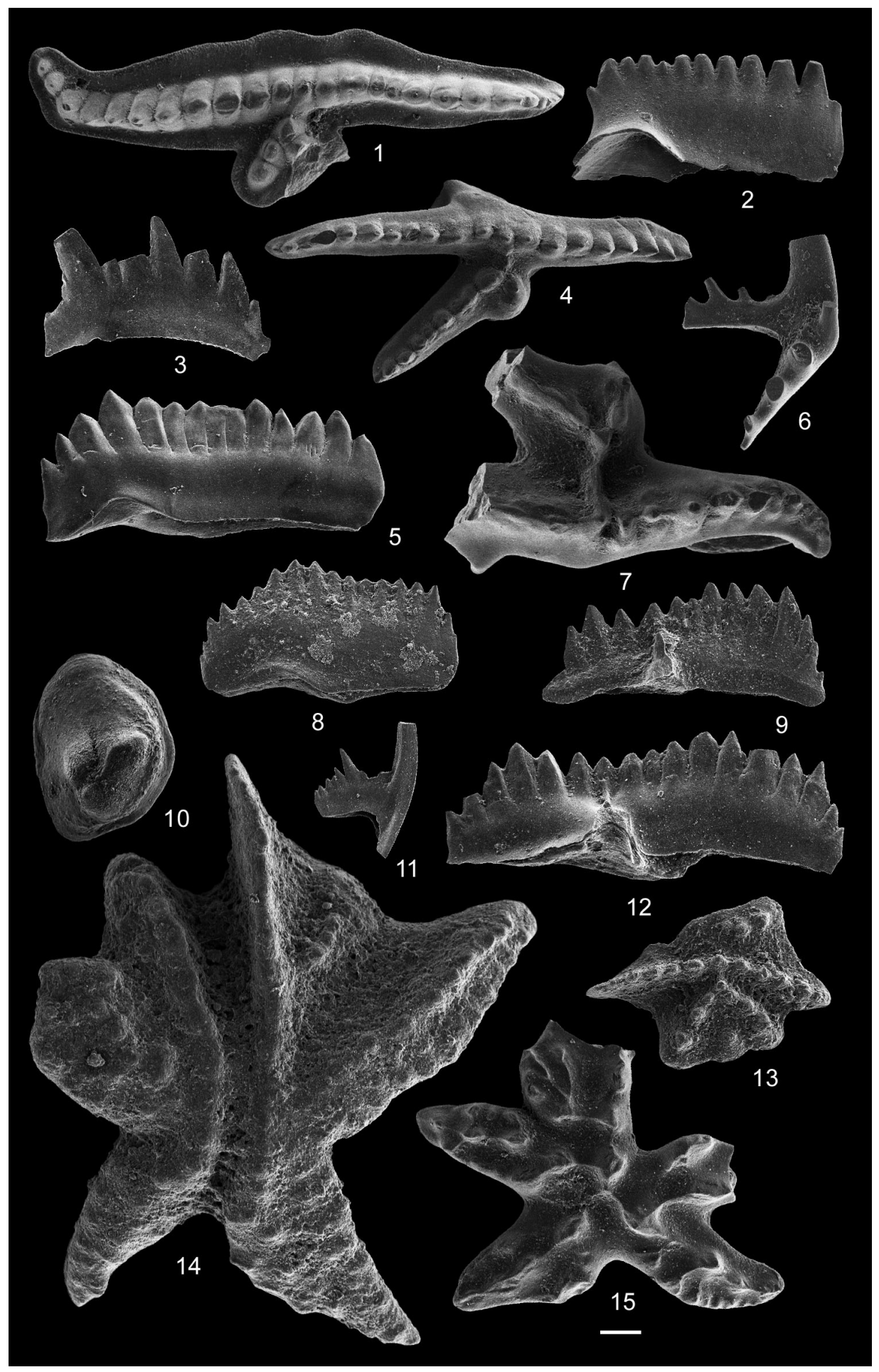




\section{DISCUSSION AND CONCLUSIONS}

\section{General notes}

Comparison of the frequency patterns of chitinozoans, scolecodonts, and conodonts shows that chitinozoans represent the most common group (Fig. 6). Their abundance as well as relative frequency of individual species and genera is highly variable. The variations are not necessarily related to the changes in lithology, at least as revealed by the methods used in this study. Also, the current sampling density is too low to determine whether such abrupt changes in abundance and/or assemblage composition are gradual but rapid, or instantaneous, possibly marking missing time and rock. Closely similar chitinozoan dynamics was observed also in the lower Wenlock of Gotland (Laufeld 1979).

Jawed polychaetes constitute the most diverse but least varying group. The amplitude of their abundance curve is the lowest - the minimum and maximum abundances of scolecodonts differ ca 15 times, whilst the corresponding estimate is more than 150 for chitinozoans and more than 200 for conodonts. Changes in polychaete faunas tend to be gradual rather than abrupt, which is best seen at the Llandovery-Wenlock boundary where the other two groups display a conspicuous change (partly on account of the gap). In comparison with chitinozoans and conodonts, jawed polychaetes include more species ranging through and beyond

\section{Explanation of Plate III}

Figs 1-15. Selected conodonts from the Telychian and lowermost Sheinwoodian. All specimens $\times 60$, scale bar corresponds to $100 \mu \mathrm{m}$. 1. Pterospathodus amorphognathoides amorphognathoides Walliser, Pa element, upper view, GIT 493-46, sample OM4-38, depth $70.08 \mathrm{~m}$, Velise Formation, Llandovery. 2. Kockelella ranuliformis (Walliser), Pa element, lateral view, GIT 493-47, depth $76.70 \mathrm{~m}$, Velise Formation, Llandovery. 3. Ozarkodina excavata (Branson \& Mehl), Pa element, lateral view, GIT 493-48, sample OM4-41, depth 64.23 m, Jaani Formation, Wenlock. 4. Pterospathodus amorphognathoides lithuanicus Brazauskas, Pa element, upper view, GIT 493-49, sample OM4-36, depth $74.10 \mathrm{~m}$, Velise Formation, Llandovery. 5. Ozarkodina polinclinata polinclinata (Nicoll \& Rexroad), Pa element, lateral view, GIT 493-50, sample OM4-38, depth 70.08 m, Velise Formation, Llandovery. 6. Oulodus? petilus (Nicoll \& Rexroad), Sc element, lateral view, GIT 493-51, depth $78.60 \mathrm{~m}$, Velise Formation, Llandovery. 7. Pterospathodus amorphognathoides lennarti Männik, Pa element, upper view, GIT 493-52, depth 74.55 m, Velise Formation, Llandovery. 8. Ozarkodina polinclinata estonica Männik, Pa element, lateral view, GIT 493-53, sample M-1010, depth $81.22 \mathrm{~m}$, Velise Formation, Llandovery. 9. Pterospathodus eopennatus ssp. n. 2 Männik, Pa element, lateral view, GIT 493-54, sample M-1010, depth 81.22 m, Velise Formation, Llandovery. 10. Pseudooneotodus tricornis Drygant, upper view, GIT 493-55, sample M-1011, depth $80.40 \mathrm{~m}$, Velise Formation, Llandovery. 11. Pterospathodus amorphognathoides angulatus (Walliser), Sc2 element, lateral view, GIT 493-56, sample OM4-34, depth 78.20 m, Velise Formation, Llandovery. 12. Pterospathodus amorphognathoides angulatus (Walliser), Pa element, lateral view, GIT 493-57, sample OM4-34, depth $78.20 \mathrm{~m}$, Velise Formation, Llandovery. 13. Apsidognathus tuberculatus Walliser, platform element, upper view, GIT 493-58, sample M-1011, depth $80.40 \mathrm{~m}$, Velise Formation, Llandovery. 14. Aulacognathus kuehni Mostler, Pa element, upper view, GIT 493-59, depth 83.55 m, Rumba Formation, Llandovery. 15. Distomodus staurognathoides (Walliser), Pa element, upper view, GIT 493-60, depth 76.70 m, Velise Formation, Llandovery. 

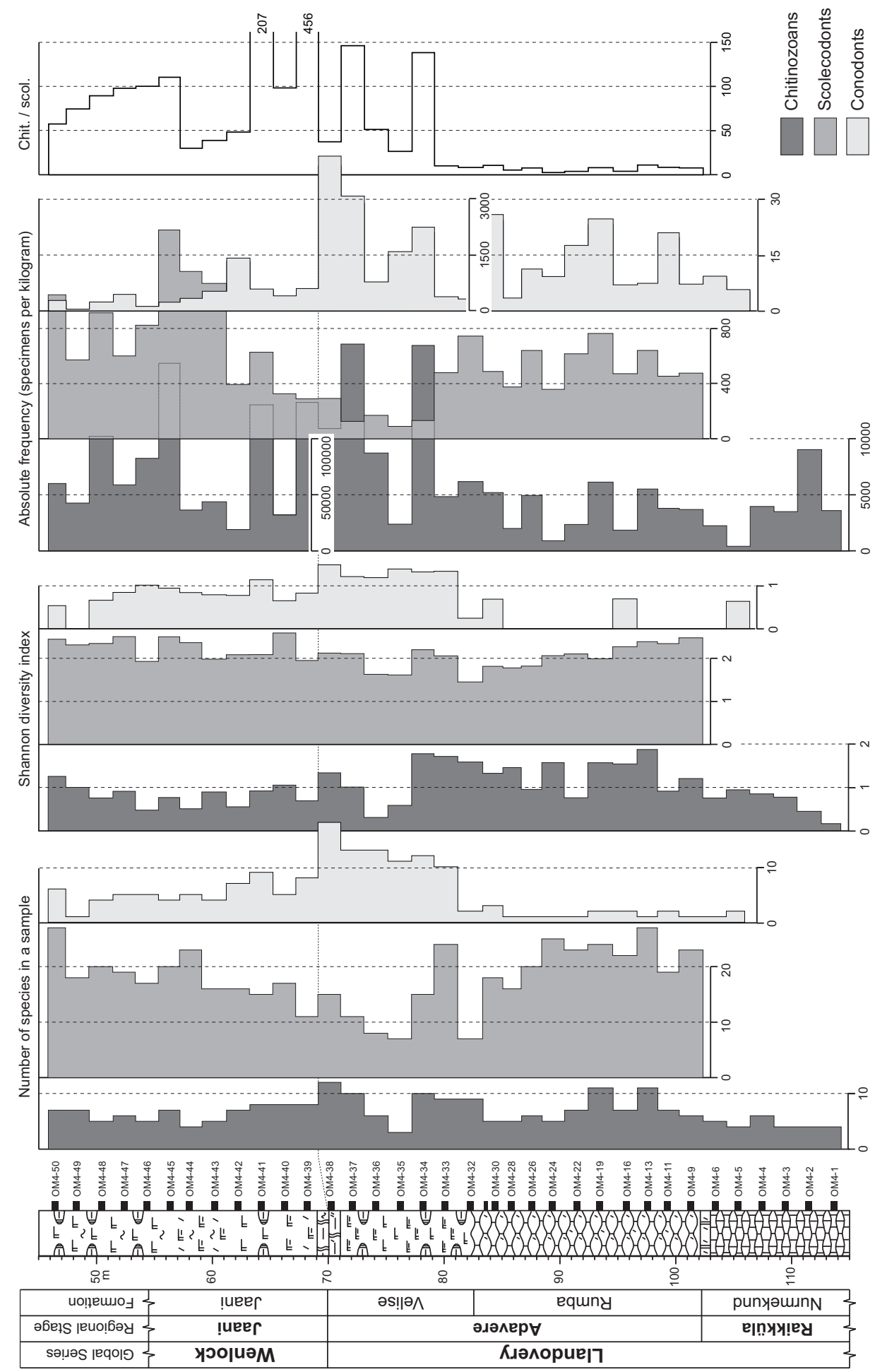
the interval studied (a few are coming from the Late Ordovician). Relatively long ranges and slow evolution of jawed polychaetes have been reported earlier (Bergman 1989; Eriksson et al. 2004; Hints 1998; Hints \& Eriksson in press; Szaniawski \& Imajima 1996). Since scolecodonts may be equally diverse and abundant in different environmental settings, using them in facies interpretations at the group level (i.e., abundant occurrence of scolecodonts indicates particular settings) is an oversimplification. However, certain species/genera may turn very useful for this purpose, e.g., Pistoprion denotes relatively shallower water facies and Rhytiprion deeper water muddy conditions (see also discussion by Bergman et al. 2003).

Changes in the conodont succession in the interval studied are assumed to reflect primarily general evolutionary trends of faunas (Männik \& Viira 1993; Männik 2001) rather than faunal shifts due to the facies variations. Poor conodont faunas in the Rumba Formation correspond to the lower part of the low-diversity episode of the late Llandovery-early Wenlock faunal cycle sensu Männik \& Viira (1993) and rich faunas in the Velise Formation to the high-diversity episode of the same cycle. This cycle was terminated by the Ireviken Event. The faunas above this level correspond to the low-diversity episode of the middle Wenlock-middle Ludlow cycle sensu Männik \& Viira (1993). However, it is most probable that unfavourable ecological conditions in the region in Rumba time still strengthened the effect of the low-diversity episode and are responsible for the rare occurrences of conodonts in the corresponding formation.

The current data are inconclusive for detecting significant correlation between the three groups studied. This can be taken as an indication of that chitinozoans, jawed polychaetes, and conodonts had no direct relationships via food webs. They were, indeed, influenced by the same environmental settings, as well as oceanic and biotic events, but to a different extent due to a different mode of life.

\section{Plankton/benthos ratio}

Nestor (1994) has provided 7-grade estimations of the plankton/benthos ratio in acid-resistant microfossil assemblages (mainly chitinozoans representing the plankton, and scolecodonts, melanoscleritoids, and foraminiferans representing the benthos). This ratio might be very useful for general biofacies interpretation, but is too rough for revealing smaller-scale changes in assemblages and difficult to compare with other authors' studies. The current data set allows further quantification of this measure using the ratio of the abundance of chitinozoans to that of scolecodonts per kilogram of rock.

Fig. 6. Comparison of absolute frequency and diversity of chitinozoans, scolecodonts, and conodonts. Note that in the chitinozoan abundance curve two different scales, with maximums of 10000 and 100000 , are used in order to display frequency changes throughout the interval. The same applies to conodonts where scales with maximums of 30 and 3000 are used. Chit./scol. denotes the ratio of the abundance of chitinozoans to that of scolecodonts, both calculated as specimens per kilogram. For lithological key see Fig. 2. 
The Rumba and lowermost Velise formations are characterized by a rather low chitinozoan/scolecodont ratio, ca 10 or less vesicles per scolecodont (but note how the scolecodonts were counted). This ratio increases notably in overlying strata, to 450 in sample OM4-39, just above the Llandovery-Wenlock boundary, and fluctuates strongly. The decreasing trend in the upper part of the Jaani Formation may be another indication of gradual shallowing and facies change as revealed by other criteria. It needs further clarification whether the change between samples OM4-44 and OM4-45 is random or has a reasonable explanation.

Of the sections published by Nestor (1994), the Varbla borehole is geographically closest to the Paatsalu section. The semi-quantitative plankton/benthos ratios provided for the Varbla section (Nestor 1994, fig. 15/2) are in a good agreement with the current data.

\section{Abundance and relative frequency}

The successive stratigraphical units contain different faunal assemblages. The Nurmekund and Rumba formations representing relatively shallower sea conditions are characterized by abundant and diverse scolecodonts, low abundance but high diversity of chitinozoans, and very rare conodonts. The Velise Formation, except for its lowermost part, exhibits reduced frequency of scolecodonts, slightly increasing frequency of chitinozoans, and a marked increase in conodonts. The Jaani Formation displays significant growth in absolute frequency of chitinozoans and scolecodonts. Conodonts, in contrast, decrease in abundance in the Jaani Formation compared to the underlying Velise strata.

Besides this broad-scale group-level frequency pattern, smaller-scale fluctuations in abundance can be observed. In this respect the Rumba Formation provides an interesting example where all three groups show a rather good positive correlation (Fig. 6). Moreover, the faunal frequency curves correlate positively with the content of insoluble residue (which is mainly clay) and even more so with the content of mud (which is everything except for the bioclastic material). The best correlation (correlation coefficient over-0.8) is observed between the abundance of chitinozoans $(\mathrm{n} / \mathrm{g})$ and the content of bioclastic material (\%). Since the three groups studied have unlikely shared their environmental preferences, a plausible explanation for this correlation would be fluctuations in the deposition rate and/or degree of compaction, both of which influence the yield of fossils regardless of their habits and origin. Although a more rigorous data set is necessary for statistical testing, this example points to a possible utility of microfossil frequency patterns in sedimentology.

It should be noted, however, that the relationship described above is not so clearly observed in other parts of the studied interval. In the Jaani Formation, especially in its upper part, the frequency curves of chitinozoans and scolecodonts are in good correspondence, but conodonts display a somewhat different pattern, partly reverse to those of chitinozoans and scolecodonts. For instance, the peak in the conodont frequency curve is in sample OM4-42, where chitinozoans and scolecodonts display minimum values, and in sample OM4-45, where the maximum abundance of both chitinozoans and scolecodonts is observed, and conodonts 
display relatively low values. The faunal frequency curves do not agree well with any of the rock-characterizing parameters.

It seems, therefore, that in the case of the Jaani Formation the changes caused by a varying deposition rate and compaction are overprinted by far more important primary variations in frequency. These, in turn, may be caused by environmental changes which are not revealed by the currently used analysis.

The frequency curves of scolecodonts and chitinozoans display almost no change at the Rumba-Velise transition - the level of the most conspicuous lithological change (both in terms of mineralogical and structural composition; note that the increased abundance of scolecodonts in sample OM4-32 may be due to inadequate sample size). This boundary is transitional also with regard to frequency patterns of individual polychaete and chitinozoan taxa. A significant faunal turnover occurs somewhat later, marked by, e.g., the disappearance of Pistoprion sp. A and Tetraprion sp. A, and an increase in the relative frequency of Ancyrochitina spp., "Mochtyella" sp. D, and Kettnerites spp. (Figs 3, 4). Conodonts, in contrast, display a conspicuous increase in abundance at the Rumba-Velise boundary.

This poses two intriguing questions. First, assuming that the frequency changes in the Rumba Formation are related to the deposition rate and/or compaction, do the invariable frequency curves of chitinozoans and scolecodonts indicate that there was no difference in the deposition rate and/or compaction between rather different lithologies? Second, the relative frequencies of different chitinozoans and scolecodonts change also insignificantly at this level. Does that mean that the marked lithological change reflects no environmental shift to cause faunas to reorganize?

Temporal mixing is one possible explanation for the observed discrepancy between faunal and lithological changes (see Kowalewski \& Bambach 2003 for examples of temporal mixing and further references). Simply put, this means that the microfossils recovered from the basal part of the Velise marlstones may predate the strata that contain them. However, if that is the case, one might expect elements of new faunas to co-occur with the redeposited, time averaged material, which seems not to be the case. One might then expect a similar situation to appear, for instance, at the Velise-Jaani boundary, which is also not the case - not a single specimen of Angochitina longicollis or Pterospathodus has been recovered in the lower part of the Jaani Formation. Another possibility is that scolecodonts and chitinozoans were more tolerant to environmental change than conodonts and their associations were reorganized with some delay. An unambiguous answer to these questions cannot currently be provided, but data from other sections could help to solve the problem in the future.

\section{Diversity}

Unlike the plain number of species, the diversity indices enable using quantitative data and take into account differences in sample size. Several diversity indices were calculated for each group using the PAST software package (Hammer et al. 2001, http://folk.uio.no/ohammer/past/). The Shannon index is 
most commonly used in palaeontology (Krebs 1989) and was employed also in this study. It equals 0 where one species is present and rises with the increasing number of species and evenness. Closely similar results were obtained by other indices, like the Simpson diversity index.

Figure 6 shows the number of species per sample and the Shannon diversity index for all three groups. It appears that the diversity index curves match rather well the corresponding species-per-sample curves, but reveal some trends in the diversity patterns more clearly. For instance, the continuously decreasing diversity of jawed polychaetes throughout the Rumba and lowermost Velise formations and increase in the diversity of chitinozoans in the lower part of the interval studied (samples OM4-1 to OM4-34) seem to be not occasional and may well be related to gradual environmental change and deepening of the basin. The diversity trends indicate that an important change in chitinozoan and polychaete assemblages occurred in the lowermost Velise Formation between samples OM4-34 and OM4-35. Interestingly, however, marked changes in frequency took place slightly below that level, between samples OM4-33 and OM4-34. Conodont diversity is particularly high in sample OM4-33. The actual change in conodont faunas, including a diversity boost, occurred earlier, but cannot be precisely recorded due to insufficient size of sample OM4-32. The Llandovery-Wenlock boundary displays a diversity drop in all groups, which is rather limited in polychaete faunas but severe in conodont assemblages.

Comparison of the currently documented taxic diversity with the data reported by Jaanusson (1979, fig. 75 ; note an erroneously added "\%" sign on $x$-axis) shows that the values obtained in Gotland and Estonia are rather similar for chitinozoans. The conodonts recovered in the Paatsalu core are difficult to compare with Gotland material since some genera are not fully subdivided into species; however, preliminary numbers are also very similar. Concerning scolecodonts, the numbers reported in the present study are much higher, but this is primarily due to the progress in polychaete studies since the 1980s (see Eriksson et al. 2004 and references therein).

\section{Concluding remarks}

Fossil frequency patterns provide useful information for different palaeontological and geological questions. However, the frequency patterns cannot always be fully explained and unequivocally interpreted on the basis of one section only. For instance, it is complicated to differentiate between faunal shifts sensu Jaanusson $(1976,1979)$ and immigrations or broader evolutionary changes in faunas. It remains currently unclear whether the above described species-level frequency changes can be traced spatially and whether they occur in the same stratigraphical position elsewhere, or how the frequency changes are related to depositional cycles such as those in the Rumba Formation. More complete sections are necessary for studying the biotic effects of the Ireviken Event in detail. To overcome these deficiencies, we plan to extend our study to other localities and increase the sampling density at the most intriguing levels. 


\section{ACKNOWLEDGEMENTS}

We are grateful to Dimitri Kaljo (Tallinn) and Mats E. Eriksson (Lund) for carefully reading the manuscript and for many invaluable remarks and suggestions. This study is a contribution to IGCP Project 503 and was supported by the Estonian Science Foundation grants Nos 5920, 6127, and 5406.

\section{REFERENCES}

Bergman, C. 1979. Polychaete jaws. In Lower Wenlock Faunal and Floral Dynamics - Vattenfallet Section, Gotland (Jaanusson, V., Laufeld, S. \& Skoglund, R., eds). Sver. Geol. Unders., C762, 92-102.

Bergman, C. F. 1989. Silurian paulinitid polychaetes from Gotland. Fossils Strata, 25.

Bergman, C. F., Eriksson, M. E. \& Calner, M. 2003. The jawed annelid Rhytiprion magnus KielanJaworowska, 1966 - a muddy bottom dweller. GFF, 125, 191-199.

Boucot, A. J. 1975. Evolution and Extinction Rate Controls. Elsevier, Amsterdam.

Einasto, R., Nestor, H., Kala, E. \& Kajak, K. 1972. Correlation of Upper Llandoverian sections in West Estonia. Eesti NSV Tead. Akad. Toim. Keemia Geol., 21, 333-343 (in Russian).

Eriksson, M. 1997. Lower Silurian polychaetaspid polychaetes from Gotland, Sweden. GFF, 119, 213-230.

Eriksson, M. 2001. Silurian ramphoprionid polychaetes from Gotland, Sweden. J. Paleontol., 75, $993-1015$.

Eriksson, M. 2002. The palaeobiogeography of Silurian ramphoprionid polychaete annelids. Palaeontology, 45, 985-996.

Eriksson, M. E. 2006a. The Silurian Ireviken Event and vagile benthic faunal turnovers (Polychaeta; Eunicida) on Gotland, Sweden. GFF, 128 (in press).

Eriksson, M. E. 2006b. Polychaete jaw apparatuses and scolecodonts from the Ireviken Event interval of Gotland, Sweden. GFF, 128 (in press).

Eriksson, M. E., Bergman, C. F. \& Jeppsson, L. 2004. Silurian scolecodonts. Rev. Palaeobot. Palynol., 131, 269-300.

Hammer, Ø., Harper, D. A. T. \& Ryan, P. D. 2001. Past: Paleontological Statistics Software Package for Education and Data Analysis. Palaeontol. Electronica, 4, art. 4, 9 pp. [http://palaeoelectronica.org/2001_1/past/issue1_01.htm].

Harris, M., Sheehan, P., Ainsaar, L., Hints, L., Männik, P., Nõlvak, J. \& Rubel, M. 2005. The Lower Silurian of Estonia: facies, sequences and basin filling. In The Sixth Baltic Stratigrapical Conference, August 23-25 St. Petersburg, Russia (Koren', T., Evdokimova, I. \& Tolmachova, T., eds), pp. 30-33. VSEGEI, St. Petersburg.

Hints, O. \& Eriksson, M. E. Diversification and biogeography of scolecodont-bearing polychaetes in the Ordovician. Palaeogeogr. Palaeoclimatol. Palaeoecol. (in press).

Hints, O. 1998. Late Viruan (Ordovician) polychaete jaws from North Estonia and the St. Petersburg Region. Acta Palaeontol. Polonica, 43, 471-516.

Hints, O. 1999. Two new polychaete families from the Upper Ordovician of Estonia. Palaeontology, 42, 897-906.

Hints, O. 2000. Ordovician eunicid polychaetes of Estonia and surrounding areas: a review of their distribution and diversification. Rev. Palaeobot. Palynol., 113, 41-55.

Hints, O. 2001. Distribution of scolecodonts. In Valga (10) Drill Core (Põldvere, A., ed.). Estonian Geol. Sections, 3, 12-14.

Hints, O., Bergman, C. F. \& Märss, T. 2000. Silurian jawed polychaetes from Cornwallis and Baillie-Hamilton islands, Canadian Arctic. In Pan-Arctic Palaeozoic Tectonics, Evolution of Basins and Faunas (Antoshkina, A., Malysheva, E. \& Wilson, M. V. H., eds). Ichtyolith Issues, 6, 35-38. 
Hints, O., Hints, L., Meidla, T. \& Sohar, K. 2003. Biotic effects of the Ordovician Kinnekulle ashfall recorded in northern Estonia. Bull. Geol. Soc. Denmark, 50, 115-123.

Jaanusson, V. 1976. Faunal dynamics in the Middle Ordovician (Viruan) of Balto-Scandia. In The Ordovician System: Proceedings of a Palaeontological Association Symposium (Bassett, M. G., ed.), pp. 301-326. University of Wales Press and National Museum of Wales, Cardiff.

Jaanusson, V. 1979. Ecology and faunal dynamics. In Lower Wenlock Faunal and Floral Dynamics - Vattenfallet Section, Gotland (Jaanusson, V., Laufeld, S. \& Skoglund, R., eds). Sver. Geol. Unders., C762, 92-102.

Jaanusson, V., Laufeld, S. \& Skoglund, R. (eds). 1979. Lower Wenlock faunal and floral dynamics - Vattenfallet Section, Gotland. Sver. Geol. Unders., C762.

Jeppsson, L. 1979. Conodonts. In Lower Wenlock Faunal and Floral Dynamics - Vattenfallet Section, Gotland (Jaanusson, V., Laufeld, S. \& Skoglund, R., eds). Sver. Geol. Unders., C762, 225-248.

Jeppsson, L. 2005. Oceanic and climatic cycles. In The Dynamic Silurian Earth (Eriksson, M. E. \& Calner, M., eds). Geol. Surv. Sweden. Rapporter och meddelanden, 121, 17-20.

Jeppsson, L. \& Männik, P. 1993. High-resolution correlations between Gotland and Estonia near the base of the Wenlock. Terra Nova, 5, 348-358.

Kaljo, D. L. (ed.). 1970. The Silurian of Estonia. Valgus, Tallinn (in Russian).

Kaljo, D., Viira, V., Märss, T. \& Nestor, V. 1986. The nektic, nektobenthic and planktonic communities (fishes, agnathans, conodonts, graptolites, chitinozoans) of the East Baltic Silurian. In Theory and Practice of Ecostratigraphy (Kaljo, D. \& Klaamann, E., eds), pp. 127-136. Valgus, Tallinn.

Kiipli, E. 2004. Redox changes in the deep shelf of the East Baltic Basin in the Aeronian and early Telychian (early Silurian). Proc. Estonian Acad. Sci. Geol., 53, 94-124.

Kowalewski, M. \& Bambach, R. K. 2003. The limits of Paleontological Resolution. In HighResolution Approaches in Stratigraphic Paleontology (Harries, P. J., ed.), pp. 1-48. Kluwer Academic Publishers, London.

Krebs, C. J. 1989. Ecological Methodology. Harper \& Row Publishers, New York.

Laufeld, S. 1974. Silurian Chitinozoa from Gotland. Fossils Strata, 5.

Laufeld, S. 1979. Chitinozoans. In Lower Wenlock Faunal and Floral Dynamics - Vattenfallet Section, Gotland (Jaanusson, V., Laufeld, S. \& Skoglund, R., eds). Sver. Geol. Unders., C762, $70-76$.

Loydell, D. K., Kaljo, D. \& Männik, P. 1998. Integrated biostratigraphy of the lower Silurian of the Ohesaare core, Saaremaa, Estonia. Geol. Mag., 135, 769-783.

Loydell, D. K., Männik, P. \& Nestor, V. 2003. Integrated biostratigraphy of the lower Silurian of the Aizpute-41 core, Latvia. Geol. Mag., 140, 205-229.

Männik, P. 2001. Evolution of early Silurian conodont faunas, and high-resolution stratigraphy. In Evolution of Life on the Earth. Proceedings of the II International Symposium "Evolution of Life on the Earth", November 12-15, 2001, Tomsk (Podobina, V. M., ed.), pp. 202-205. NTL, Tomsk.

Männik, P. 2003. Distribution of conodonts. In Ruhnu (500) Drill Core (Põldvere, A., ed.). Estonian Geol. Sections, 5, 17-23.

Männik, P. \& Viira, V. 1993. Events in the conodont history during the Silurian in Estonia. Proc. Estonian Acad. Sci. Geol., 42, 58-69.

Männil, R. M. \& Zaslavskaya, N. M. 1985. Silurian polychaetes from the northern Siberia. Tr. In-ta Geol. Geofiz. SO AN SSSR, 615, 98-119 (in Russian).

Nestor, H. 1997. Sedimentary cover. Silurian. In Geology and Mineral Resources of Estonia (Raukas, A. \& Teedumäe, A., eds), pp. 89-106. Estonian Academy Publishers, Tallinn.

Nestor, H. \& Einasto, R. 1997. Formation of the territory. Ordovician and Silurian carbonate sedimentation basin. In Geology and Mineral Resources of Estonia (Raukas, A. \& Teedumäe, A., eds), pp. 52-55. Estonian Academy Publishers, Tallinn. 
Nestor, H. \& Nestor, V. 2002. Upper Llandovery to middle Wenlock (Silurian) lithostratigraphy and chitinozoan biostratigraphy in southwestern Estonia and northernmost Latvia. Proc. Estonian Acad. Sci. Geol., 51, 67-87.

Nestor, H., Einasto, R., Männik, P. \& Nestor, V. 2003. Correlation of lower-middle Llandovery sections in central and southern Estonia and sedimentation cycles of lime muds. Proc. Estonian Acad. Sci. Geol., 52, 3-27.

Nestor, V. 1976. A microplankton correlation of boring sections of the Raikküla Stage, Estonia. Eesti NSV Tead. Akad. Toim. Keemia Geol., 25, 319-324 (in Russian).

Nestor, V. 1994. Early Silurian Chitinozoans of Estonia and North Latvia. Estonian Academy Publishers, Tallinn.

Nestor, V. 2005. Chitinozoans of the Margachitina margaritana Biozone and the LlandoveryWenlock boundary in West Estonian drill cores. Proc. Estonian Acad. Sci. Geol., 54, 87-111.

Szaniawski, H. \& Imajima, M. 1996. Hartmaniellidae - living fossils among polychaetes. Acta Palaeontol. Polonica, 41, 111-125.

\title{
Kitiinikute, skolekodontide ja konodontide arvukuse dünaamika Paatsalu läbilõike Ülem-Llandoverys ja Alam-Wenlockis
}

\author{
Olle Hints, Mairy Killing, Peep Männik ja Viiu Nestor
}

On kirjeldatud Adavere ja Jaani lademe kitiinikute, skolekodontide ja konodontide arvukuse dünaamikat Paatsalu puuraugus. Ligi 50 liigiga esindatud kitiinikute arvukus ületab skolekodontide ja konodontide hulga 10-100-kordselt. Lõugsed polüheedid on 60 liigiga kõige mitmekesisem ja samas kõige vähem varieeruv grupp, skolekodontide hulk kivimis ulatub mitme tuhande eksemplarini kilogrammi kohta. Konodontide levikupilt, mida iseloomustavad suurimad absoluutse ja suhtelise arvukuse kõikumised, on enim mõjutatud nii fauna üldisematest arengusuundadest kui ka keskkonnatingimustest.

Rumba kihistut iseloomustab rikkalik polüheedifauna, vähearvukad, kuid mitmekesised kitiinikud ja väga harvad konodondid. Fauna arvukuse ja litoloogia vaheline korrelatsioon Rumba kihistus viitab settekiiruse või kompaktsiooni variatsioonidele. Märkimisväärse litoloogilise muutusega Rumba ja Velise kihistu piiril ei toimu murrangut kitiinikute ja polüheetide kooslustes; oluline muutus, mis kajastub taksonoomilise koosseisu ja arvukuse muutustes, leiab aset mõnevõrra hiljem. Velise kihistut iseloomustab konodontide suur arvukus ning mitmekesisus ja skolekodontide arvukuse langus. Llandovery-Wenlocki piiril toimub konodondi- ja kitiinikufaunas järsk taksonoomilise koosseisu muutus. Lisaks kasvab kitiinikute arvukus piiril ligi 10-kordseks, konodontide arvukus ja mõlema rühma mitmekesisus aga langeb. Mõnevõrra väiksemad muutused on jälgitavad polüheedifauna taksonoomilises koosseisus, skolekodontide arvukuse ja mitmekesisuse muutused on aga Llandovery-Wenlocki piiril järkjärgulised. Jaani kihistut iseloomustab kitiinikute ning skolekodontide maksimumarvukus ja konodontide vähenenud hulk ning mitmekesisus, mis tuleneb eelkõige Irevikeni sündmuse mõjust. 